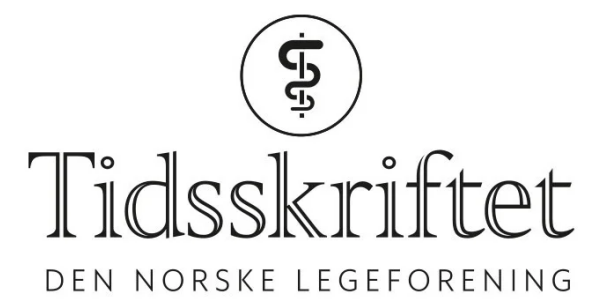

\title{
STEM NEI!
}

TIDLIGERE I TIDSSKRIFTET

SYNNE LOFSTAD

synne.lofstad@hotmail.com

Redaksjonssjef i Æsculap

Hvor politisk farget Æsculap har vært, har variert med skiftende redaksjoner og fra tiår til tiår. På starten av 1970tallet så man en klar sosialistisk linje i Æsculaps redaksjon, og dermed også i stoffet. Det hele toppet seg med folkeavstemningen om hvorvidt Norge skulle gå inn i EEC, EUs forløper, der redaksjonen tok et klart standpunkt (Æsculap 1972; 52:1).

\section{For siste gang - STEM NEI!}

Vi nærmer oss dagen for folkeavstemningen om EEC. De fleste av oss har tatt et standpunkt, men fremdeles er det mange som ikke vet. 


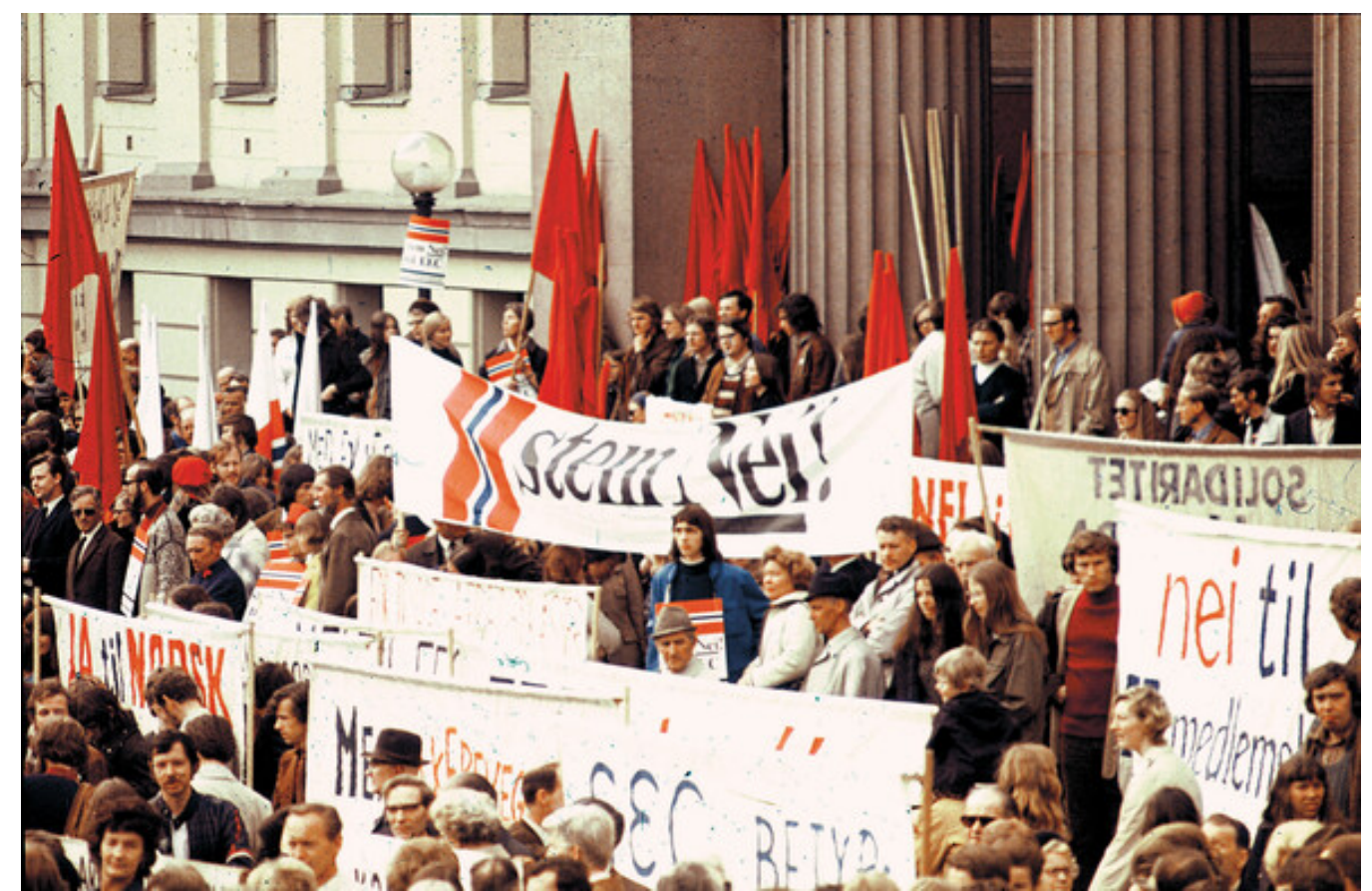

Massemøte mot EEC på Universitetsplassen i 1972. Foto: Samfoto / NTB Scanpix

Her i Æsculap har vi i det siste skrevet mye om følgene av å gå inn i EEC. Vi har prøvd å få fram tydeligst mulig hvorledes et medlemskap vil forsterke de faktorer i den sosiale utviklingen som gir sykdom. Dette gjelder $\emptyset \mathrm{kt}$ sentralisering av arbeidsplasser, flere pendlere, flytting av arbeidskraft fra «lite» produktive yrker, kort sagt: for å oppfylle målsettingen med EEC som er fri bevegelse for kapital og uhindret økonomisk vekst, er man villig til å produsere nye sosiale problemer. På lengre sikt frykter vi at profitt-motivet skal komme inn i behandlingen av syke.

«Et medlemskap vil forsterke de faktorer $i$ den sosiale utviklingen som gir sykdom»

I like stor grad har vi hevdet at vi som helse- og sosialarbeidere må se på følgene av et medlemskap for vår egen situasjon. På arbeidsplassene merker vi en stadig hardere rasjonalisering. Det er uttrykk for at Staten prioriterer helsevesenet lavt fordi det er «uproduktivt». Allerede det siste statsbudsjettet som vi mener var en forberedelse til EECmedlemskap, gav bare en svak stigning i utgiftene til helsevesenet, mens pengene gikk til omstrukturering av industrien o.l.

Som lønnsmottakere vil vi merke høyere priser på mange av de vanligste matvarene og økt husleie fordi rentene vil øke med ca. 2 prosent.

Vi er ikke lenger i tvil, vi sier STEM NEI!

«Som lønnsmottakere vil vi merke høyere priser på mange av de vanligste matvarene»

Bratteli forteller oss at i EEC trives sosialismen. Er det sammen med Heath, Pompidou og Strauss at Bratteli, Aspengren og Willoch skal lære oss hva sosialisme er?

Vi ønsker ikke å låse Norges framtid til gjennoppbyggingen av en ny stormaktsblokk. Vi $\emptyset$ nsker selv å kunne bestemme den politiske utviklingen. Vi vil ha selvbestemmelsesrett.

Derfor sier vi, STEM NEI!

Publisert: 4. mai 2020. Tidsskr Nor Legeforen. DOI:10.4045/tidsskr.20.0285

(C) Tidsskrift for Den norske legeforening 2023. Lastet ned fra tidsskriftet.no 26. april 2023. 
